\title{
ANTIOXIDANT ACTIVITY OF POLYSACCHARIDES EXTRACTED FROM Lentinus edodes MYCELIA AND THEIR PROTECTIVE EFFECTS ON INS-1 CELLS
}

\author{
ATIVIDADE ANTIOXIDANTE DE POLISSACARÍDEOS EXTRAÍDOS DE Lentinus \\ edodes MICÉLIO E SEUS EFEITOS PROTECTORES EM CÉLULAS INS-1
}

\author{
Jianli LIU' ${ }^{1}$; Weiyu WANG ${ }^{1}$; Hui YU ${ }^{1}$; Xiangyu CAO ${ }^{1}$; Ying WANG $^{2}$; \\ Meijia LIU'; Xiao YAN ${ }^{1}$; Hongsheng LIU $^{3}$ \\ 1. School of Life Science, Liaoning University, China. *caoxiangyu@lnu.edu.cn; 2. Soil and Fertilizer Station of Liaoning Province, \\ China; 3. Research Center for Computer Simulating and Information Processing of Bio-macromolecules of Liaoning Province, China.
}

\begin{abstract}
The disruption of the delicate balance between the generation of reactive oxygen species (ROS) and antioxidant scavenging systems can lead to many health problems. Polysaccharides extracted from fungi fruit body and myceliums have several potential health benefits. In this study, the antioxidant capacity and cell protective effects of a polysaccharide isolated from Lentinus edodes mycelia (LMP) were investigated. The antioxidant properties of LMP were screened using radical scavenging (1, 1-diphenyl-2-picrylhydrazyl (DPPH), hydroxyl, and superoxide anion), reducing power and inhibition of lipid peroxidation assays. Intracellular reactive oxygen species (ROS), in response to $\mathrm{H}_{2} \mathrm{O}_{2}$, was determined by the dichloro-dihydro-fluorescein diacetate (DCFH-DA) assay. Rat insulinoma (INS-1) cells apoptosis was detected using flow cytometry analysis. The results showed that LMP exhibited significantly strong radical scavenging activity. At the concentration of $2.0 \mathrm{mg} \mathrm{mL}^{-1}$, DPPH radical, hydroxyl radical, and superoxide anion radical scavenging rates are $80.32 \pm 2.58 \%, 92.56 \pm 3.11 \%$ and $93.73 \pm 2.82 \%$, respectively. The reducing power and inhibition of lipid peroxidation activity of LMP were as strong as the positive control. LMP alleviated the intracellular reactive oxygen species level and inhibited islet cell apoptosis significantly. The results open perspectives for studies of LMP in the treatment of diabetes.
\end{abstract}

KEYWORDS: Lentinus edodes mycelia. Polysaccharide. Antioxidant. Oxidative stress.

\section{INTRODUCTION}

The disruption of the delicate balance between the generation of reactive oxygen species (ROS) and antioxidant scavenging systems can lead to health problems (XIA et al., 2011). A large amount of evidence has suggested that the production of oxygen derived free radicals is associated with many diseases, such as diabetes, Alzheimer's and Parkinson's disease, cancer as well as being involved in the degenerative process of aging (DURACKOVÁ, 2010). To alleviate damage to the human body, many antioxidants have been synthesized industrially. However, these synthetic antioxidants are suspected of being responsible for liver damage and certain types of cancer (LI et al., 2011). Therefore, it is important to develop and use effective and non-poisonous antioxidants that are able to scavenge free radicals in human bodies and maintain health.

In recent years, there has been a growing trend of finding natural antioxidants from edible mushrooms. Lentinus edodes is a mushroom widely consumed as a nutritious dietary and medicinal food in China. Many bioactive materials have been found in this mushroom, for example, polyphenolic compounds, polysaccharides, and dietary fiber (CHEN et al., 2012). Polysaccharides are biopolymers comprised of monosaccharides linked together through glycosidic bonds (ZHANG et al., 2007). Several recent studies have indicated that Lentinus edodes polysaccharides exhibit significant antioxidant activity by scavenging free radicals (CHEN et al., 2012; TSRIMUANG et al., 2011; CHEN et al., 2008). Lentinus edodes polysaccharides can be obtained from both the fruiting body and the mycelia. Generally, mature Lentinus edodes are harvested from plastic bags about 2 months after maturity, whereas the mycelia can be cultivated through submerged cultures. Thus, the mycelia of Lentinus edodes are substitute products for the mature fruiting bodies, which can be used for the production of polysaccharides. The polysaccharides extracted from Lentinus edodes mycelia are expected to become a new biologically active substance.

Type 2 diabetes is a serious metabolic disorder characterized by defects in the control of blood glucose (RAINS et al., 2011). Pancreatic beta cell dysfunction is closely related to the development and progression of type 2 diabetes, which is related to the loss of beta cells leading to a 
reduced beta cell mass (LEE et al., 2011). There is growing evidence that beta cell loss is largely because of apoptosis induced by oxidative stress (LEE et al., 2013; LIN et al., 2012; MEHMETI, et al., 2011). Although there has been a study on the antioxidant capacity of polysaccharides from the Lentinus edodes fruiting body carried out by Tsrimuang et al (TSRIMUANG, et al., 2011), there is still relatively little information concerning the antioxidant activities of Lentinus edodes mycelia polysaccharides and their function in reducing oxidative stress in islet cells. To fully develop this polysaccharide resource and extend the potential application of Lentinus edodes mycelia, the antioxidant activities of polysaccharides extracted from Lentinus edodes mycelia harvested from submerged cultures were analyzed to screen for natural antioxidants which could be used to protect islet cells.

\section{MATERIALS AND METHODS}

\section{Preparation of Lentinus edodes mycelia polysaccharide (LMP)}

The origin of the Lentinus edodes samples is Lentinus edodes 973 stored in the School of Life Science, Liaoning University, China. The procedures for the preparation and purification of the Lentinus edodes mycelia polysaccharide have been described previously (CAO et al., 2013). Briefly, the dried fungal biomass was boiled for $4 \mathrm{~h}$. After centrifugation at $8000 \times g$ for $30 \mathrm{~min}$, the crude polysaccharide was extracted from the supernatant using four volumes of absolute ethanol $(4: 1 \mathrm{v} / \mathrm{v})$ at $4{ }^{\circ} \mathrm{C}$ for $10 \mathrm{~h}$. The supernatant was discarded after centrifugation at $8000 \times g$ for 20 min. The pellet was washed, redissolved in distilled water, applied to a Sephadex G-200 column $(2.0 \times$ $60 \mathrm{~cm}$ ) and eluted with $\mathrm{H}_{2} \mathrm{O}$ at a flow rate of $1.0 \mathrm{~mL}$ $\mathrm{min}^{-1}$. Fractions were further purified on a diethylaminoethyl (DEAE)-32 column $(2.5 \times 40$ $\mathrm{cm}$ ), with phosphate buffer solution-water used as the mobile phase and a gradient mode elution. A polysaccharide fraction identified as LMP was obtained.

\section{DPPH radical scavenging assay}

The DPPH radical scavenging assay was conducted according to the procedure of Song et al with minor modifications (SONG et al., 2010). DPPH solution $(0.1 \mathrm{mM}$, in $95 \%$ ethanol solution) was prepared and used fresh on the day of each test. Two $\mathrm{mL}$ of DPPH solution was incubated with 2.0 $\mathrm{mL}$ of the LMP solution at varying concentrations $\left(0.25,0.5,1.0,1.5\right.$, and $\left.2.0 \mathrm{mg} \mathrm{mL}^{-1}\right)$. The reaction mixture was mixed well and incubated for $30 \mathrm{~min}$ at room temperature. The absorbance was then measured at $517 \mathrm{~nm}$ against a blank. The DPPH radical scavenging activity was measured and calculated using the following equation:

Scavenging effect $(\%)=\left(1-\mathrm{A}_{\text {Sample }} / \mathrm{A}\right.$

Control $) \times 100 \%$

\section{Hydroxyl radical scavenging assay}

The hydroxyl radical scavenging effect of LMP was measured according to the procedure of He et al (2012) with slight modifications (He et al., 2012). $1.0 \mathrm{~mL}$ of sample solution at different concentrations $\left(0.25,0.5,1.0,1.5\right.$, and $\left.2.0 \mathrm{mg} \mathrm{mL}^{-1}\right)$ was mixed with $1.0 \mathrm{~mL}$ of $6 \mathrm{mM} \mathrm{FeSO}$. Then 1.0 $\mathrm{mL}$ of $6 \mathrm{mM} \mathrm{H}_{2} \mathrm{O}_{2}$ was added to start the reaction. $1.0 \mathrm{~mL}$ of $6 \mathrm{mM}$ salicylic acid was added after 10 min. Finally, the reaction mixture was incubated for $30 \mathrm{~min}$ at room temperature and the absorbance was recorded at $510 \mathrm{~nm}$ with a visible spectrometer (details of machine manufacturer, location). Ascorbic acid was used as the positive control. The scavenging activity of the polysaccharides against the hydroxyl radicals was calculated according to the following equation:

$\mathrm{HO}$ radical scavenging activity $(\%)=(1-$ $\left.\left(\mathrm{A}_{\text {sample }}-\mathrm{A}_{\text {blank }}\right) / \mathrm{A}_{\text {control }}\right) \times 100 \%$

\section{Superoxide anion radical scavenging assay}

The measurement of superoxide anion radical scavenging activity was investigated according to the method reported by Zha et al (ZHA et al., 2009). $1.0 \mathrm{~mL}$ of $86 \mu \mathrm{M}$ nitroblue tetrazolium (NBT), $1.0 \mathrm{~mL}$ of $469 \mu \mathrm{M}$ nicotinamide adenine dinucleotide (NADH), $1.0 \mathrm{~mL}$ of LMP at different concentrations $\left(0.25,0.5,1.0,1.5\right.$, and $\left.2.0 \mathrm{mg} \mathrm{mL}^{-1}\right)$ and $0.4 \mathrm{~mL}$ phenazine methosulfate (PMS) were mixed in test tubes to initiate the reaction. The reaction mixture was then incubated at ambient temperature for $5 \mathrm{~min}$ and the absorbance of the mixture solution was determined at $560 \mathrm{~nm}$ with a visible spectrometer (details of machine manufacturer, location). Ascorbic acid was used as the positive control. The superoxide anion radical scavenging capability of LMP was calculated as follows:

Scavenging activity $(\%)=\left[1-\left(\mathrm{A}_{\text {sample }}-\mathrm{A}_{\text {blank }}\right)\right.$ / $\left.\mathrm{A}_{\text {control }}\right] \times 100 \%$

\section{Reducing power assay}

The measurement of reducing power was conducted according to the method reported by Soares et al (SOARES et al., 2009). $1.0 \mathrm{~mL}$ of LMP solution at Different concentrations $(0.25,0.5,1.0$, 1.5 , and $2.0 \mathrm{mg} \mathrm{mL}^{-1}$ ) were mixed with $2.5 \mathrm{~mL}$ of 
phosphate buffer $(50 \mathrm{mM}, \mathrm{pH} 7.0)$ and $2.5 \mathrm{~mL}$ of $1 \%$ potassium ferricyanide. The mixture was then incubated at $50{ }^{\circ} \mathrm{C}$ for $20 \mathrm{~min}$. Then, $2.5 \mathrm{~mL}$ of $10 \%$ trichloroacetic acid was added to the mixture to terminate the reaction, followed by centrifuging at $3000 \times g$ for $10 \mathrm{~min}$. Finally, $1.25 \mathrm{~mL}$ of the supernatant was mixed with $1.25 \mathrm{~mL}$ of distilled water and $0.25 \mathrm{~mL}$ of a $0.1 \% \mathrm{FeCl}_{3}$ solution. The absorbance was immediately measured at $700 \mathrm{~nm}$ by using a spectrometer. Ascorbic acid was used as the positive control. A higher absorbance of the reaction mixture indicated a high reducing power.

\section{Assay for inhibition of liver lipid peroxidation}

The assay for inhibition of liver lipid peroxidation was performed using the method described by Ma et al (MA et al., 2012) with some modifications. Healthy Rat livers were washed with $0.15 \mathrm{M} \mathrm{NaCl}$ and homogenized in 10 volumes $(\mathrm{v} / \mathrm{w})$ of normal saline at $4{ }^{\circ} \mathrm{C}$. Reaction mixtures contained $2.5 \mathrm{~mL}$ of liver homogenate, $1.4 \mathrm{~mL}$ of $0.2 \mathrm{mM}$ PBS (pH 7.4), $1.0 \mathrm{~mL}$ of $10 \mu \mathrm{M}$ $\mathrm{FeSO}_{4} \cdot 7 \mathrm{H}_{2} \mathrm{O}, 2.5 \mathrm{~mL}$ of $100 \mathrm{mM}$ ascorbic acid and $1.0 \mathrm{~mL}$ of various concentrations of $\operatorname{LMP}(0.25,0.5$, $1.0,1.5$, and $2.0 \mathrm{mg} \mathrm{mL}^{-1}$ ). The mixtures were incubated at $37{ }^{\circ} \mathrm{C}$ for $30 \mathrm{~min}$, followed by centrifugation $(3000 \times \mathrm{g}, 10 \mathrm{~min})$. After the addition of $1.0 \mathrm{~mL}$ of the TBA reagent to the supernatant, the tubes were placed in a boiling water bath for 15 min. Absorbance was then measured at $530 \mathrm{~nm}$ by a spectrophotometer. The percentage of lipid peroxidation inhibition by the samples was then calculated. Ascorbic acid was used as the positive control.

\section{Measurement of intracellular ROS}

Intracellular reactive oxygen species (ROS) were measured by a fluorescent dye technique as described by Lu et al (LU et al., 2008). $1 \times 10^{5}$ INS-1 cells were seeded on plate overnight, then treated with $0.5 \mathrm{mM} \mathrm{H}_{2} \mathrm{O}_{2}$, and then incubated with or without $2.0 \mathrm{mg} \mathrm{mL}^{-1}$ LMP $3 \mathrm{~h}$. INS-1 cells were incubated for 30 min with $10 \mu \mathrm{M}$ DCFH-DA at 37 ${ }^{\circ} \mathrm{C}$ in the dark in phosphate buffered saline (PBS). Images were obtained with a fluorescence microscope with excitation at $488 \mathrm{~nm}$ and emission at $>500 \mathrm{~nm}$. The fluorescent intensities of individual cells were analyzed using the InterVision 2D program (Noran Instruments Inc, WI, USA).

\section{Flow cytometry analysis}

Flow cytometry analysis was performed to determine this event using the Annexin V-FITC Apoptosis Detection Kit (KeyGen, Nanjing, China).
Cells were seeded and treated with $0.5 \mathrm{mM} \mathrm{H}_{2} \mathrm{O}_{2}$ followed by incubating with or without $2.0 \mathrm{mg} \mathrm{mL}^{-1}$ LMP $3 \mathrm{~h}$. Cells were harvested by trypsinization, then washed twice with cold PBS and centrifuged at $1000 \times g$. About $1-5 \times 10^{5}$ cells were resuspended in $500 \mu \mathrm{L}$ of binding buffer and transferred to a flow cytometry glass tube. Five microliters of Annexin V-FITC and $5 \mu \mathrm{L}$ of propidium iodide were added and the tube was incubated in the dark for $15 \mathrm{~min}$ at room temperature. Apoptotic cells were measured using a FACScan flow cytometer.

\section{Data analysis}

Statistical analysis was performed using SPSS 18.0 (IBM Corp., Armonk, NY, USA). All data were expressed as mean \pm standard deviation (SD). Statistical comparisons were carried out using one-way analysis of variance (ANOVA) and randomized block analysis of variance. The Students-Newman-Keuls (SNK) method was employed for intergroup comparison. Associations between categorical variables were verified by the Chi-squared test. Statistical significance was determined as $p<0.05$.

\section{RESULTS AND DISCUSSION}

\section{DPPH radical scavenging activity}

DPPH (1,1-diphenyl-2-picrylhydrazyl) is a compound that has been widely used to determine the free-radical scavenging ability of different materials (CHEN et al., 2011). Alcoholic solutions of DPPH have a characteristic maximum absorption at $517 \mathrm{~nm}$. When an antioxidant that can provide electrons or hydrogen atoms is added to DPPH, the absorbance at $517 \mathrm{~nm}$ disappears because the DPPH radical is scavenged (LI et al., 2011). The scavenging ability of LMP on the DPPH radical is shown in Figure 1A. The results indicated that LMP showed evident scavenging activities on the DPPH radical in a concentration-dependent manner. High levels of scavenging abilities were found for all samples used in the test. The scavenging ability of LMP on DPPH radical was $36.69 \pm 1.98 \%$ at 0.25 $\mathrm{mg} \mathrm{mL}^{-1}$ and increased to $80.32 \pm 2.58 \%$ at $2.0 \mathrm{mg}$ $\mathrm{mL}^{-1}$ which is close to that of ascorbic acid. The scavenging ability of ascorbic acid on DPPH radical was $92.3 \pm 3.18 \%$. The $\mathrm{EC}_{50}$ value of LMP on DPPH is $0.39 \mathrm{mg} \mathrm{mL}^{-1}$, which is higher than the result of Tsrimuang et al (TSRIMUANG et al., 2011). These results indicated that LMP is a strong free radicalscavenging polysaccharide that could help prevent oxidative stress. 

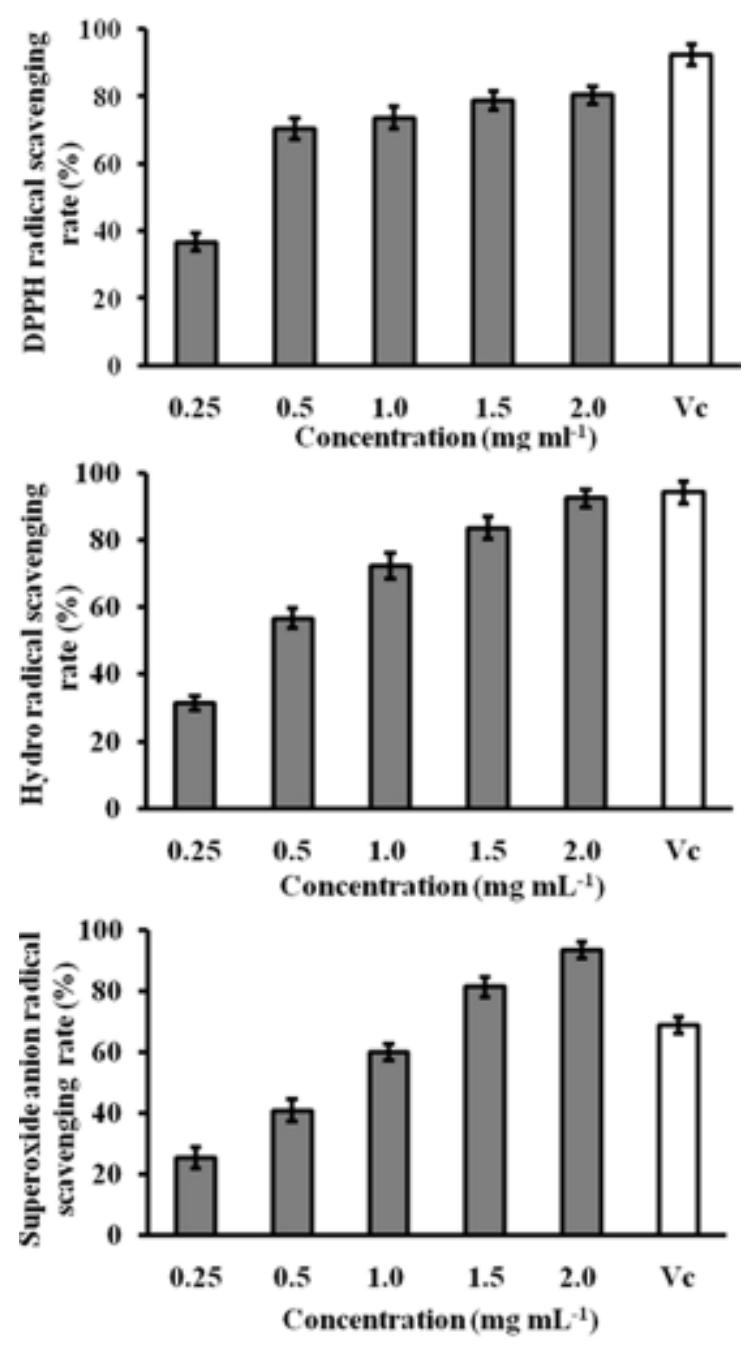

Figure 1. Free radical scavenging capacity of LMP. (A) DPPH radical scavenging activity of LMP. (B)Hydroxyl radical scavenging activity of LMP. (C) Superoxide anion scavenging activity of LMP. Vitamin C $(\mathrm{Vc})$ was used as positive control. Data were mean \pm SD of three parallel measurements.

\section{Hydroxyl radical scavenging activity}

The hydroxyl radical has a very short in vivo half-life of approximately $10^{-9} \mathrm{~s}$ and a high reactivity. This makes it a very dangerous compound in adjacent bimolecular reactions (CHEN et al., 2012). These radicals can attack biological molecules such as DNA, proteins and lipids. Thus, the removal of hydroxyl radicals is important for the protection of living systems (LIU et al., 2012). As shown in Fig. 1B, the results indicated effective hydroxyl radical scavenging activities at all tested concentrations of LMP. The scavenging ratios were improved with the increase of polysaccharide concentration. The highest scavenging rate was $92.56 \pm 3.11 \%$ at the concentration of $2.0 \mathrm{mg} \mathrm{mL}^{-1}$, which was similar to that of ascorbic acid (The scavenging rate was $95.21 \pm 4.56 \%$ ). These results show that LMP is a good scavenger for the hydroxyl radical. The scavenging activity of LMP on the hydroxyl radical is also higher than that of polysaccharides from the fruiting body of Lentinus edodes (CHEN et al., 2012). This indicates that Lentinus edodes mycelium could be a new resource of bioactive polysaccharides.

\section{Superoxide radical scavenging activity}

The superoxide radical is normally formed first in cellular oxidation reactions, and then produces other types of cell damaging free radicals and oxidizing agents (LIU et al., 2012). Although the superoxide radical is a weak oxidant in most organisms, it could produce hydrogen peroxide and hydroxyl radicals through dismutation and other types of reaction in vivo (ZHA et al., 2009). Superoxide radical is also known to indirectly initiate lipid peroxidation as a result of the formation of hydrogen peroxide. Therefore, scavenging the superoxide anion is extremely important in antioxidant work. In the present study, the scavenging ability of LMP on the superoxide 
radical was exhibited in a concentration-dependent manner as shown in Figure 1C. The highest scavenging ability of $2.0 \mathrm{mg} \mathrm{mL}^{-1} \mathrm{LMP}$ was $93.73 \pm$ $2.82 \%$, which was better than that of ascorbic acid (The scavenging rate was $69.58 \pm 2.36 \%$ ). Chen et al (2012) reported that the polysaccharides from the fruiting body of Lentinus edodes could scavenge the superoxide radical, with a scavenging rate of about 90\% (CHEN et al., 2012). Our results showed that LMP had a higher scavenging rate. However the mechanism and the basis of the LMP structure should be investigated in future studies.

\section{Reducing power}

The reducing power of a compound may serve as an indicator of its potential antioxidant activity. Higher absorbance values indicate stronger reducing power (LIU et al., 2012). The reducing power of LMP was investigated and showed in Figure 2A. As shown in the figure, the reducing power of the samples correlated well with increasing concentrations. At the lower concentration, the reducing power was far lower than that of ascorbic acid. However, at the higher concentration, the reducing power of LMP was close to that of ascorbic acid. The reducing power of
LMP in our data suggested that it was likely to contribute to the observed antioxidant effect.

\section{Activity of inhibition on liver lipid peroxidation}

The liver peroxidation inhibition activity of LMP is shown in Figure 2B, The data revealed that LMP demonstrated great capacity for the inhibition of lipid peroxidation. The inhibition rate of LMP increased from $12.53 \pm 1.22 \%$ to $61.76 \pm 3.38 \%$ as the concentration of LMP increased from 0.25 to 2.0 $\mathrm{mg} \mathrm{mL}^{-1}$, suggesting that LMP possesses relatively a strong liver peroxidation capacity and the inhibitory effects were concentration dependent. In the concentration range tested, the inhibiting effect of LMP was lower than that of ascorbic acid. It is generally admitted that the initiation of a peroxidation sequence in a cell or polyunsaturated fatty acid is because of the abstraction of a hydrogen atom from the double bond in the fatty acid (MA et al., 2012). Many studies showed that lipid peroxidation is associated with various pathological events, such as insulin resistance, inflammation, postischemic reperfusion injury, atherosclerosis, ethanol toxicity, and even cancer. (MIRMIRAN P et al., 2014; WANG et al., 2012). Therefore, it is very important for health to prevent the lipid peroxidation.
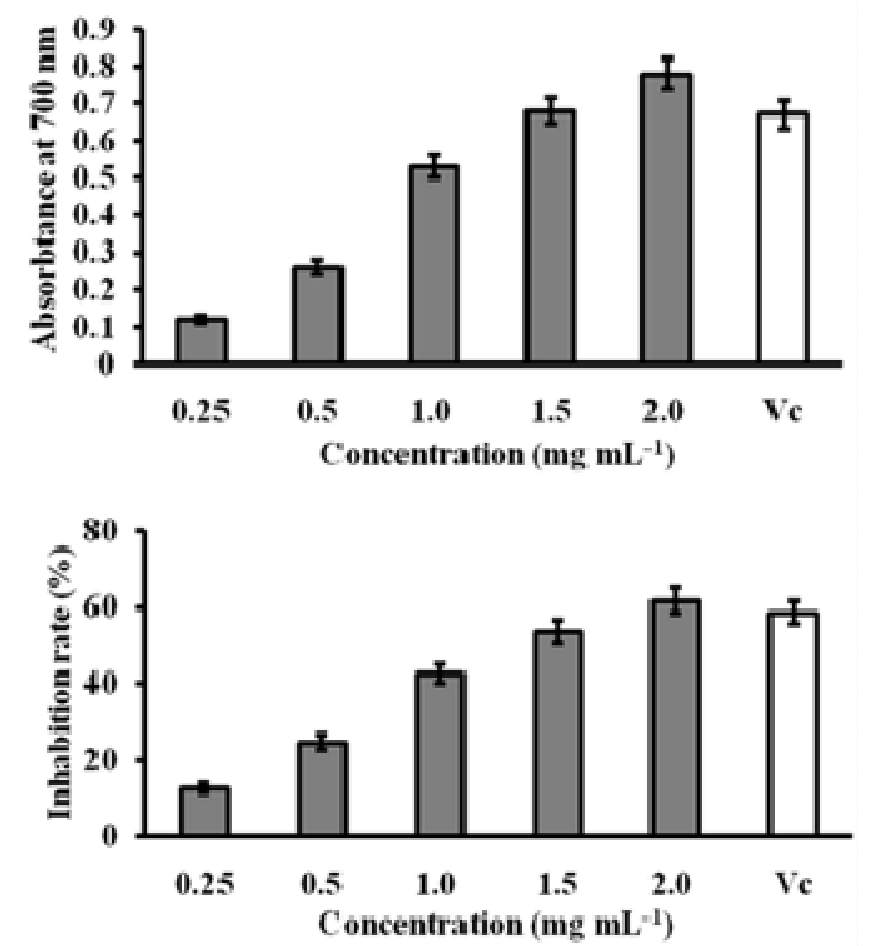

Figure 2. Reducing powers and Inhibitory activity on liver lipid peroxidation of LMP. (A) Reducing power of LMP. (B) Inhibitory activity on liver lipid peroxidation of LMP. Data were mean \pm SD of three parallel measurements. 


\section{LMP attenuate intracellular ROS}

The antioxidant capacity in $\beta$ cells is very low because of the weak expression of antioxidant enzymes such as glutathione peroxidase and superoxide dismutase in pancreatic islets compared with that in various other tissues (FUJIMOTO et al., 2011). It is believed that the generation of ROS ultimately culminates in $\beta$ cell dysfunction and death (MCCABE et al., 2006). As shown in Figure $3 \mathrm{~A}$, many INS-1 cells were detached within $3 \mathrm{~h}$ of $\mathrm{H}_{2} \mathrm{O}_{2}$ loading. Most of the LMP loaded cells treated with $\mathrm{H}_{2} \mathrm{O}_{2}$ remained adherent. The data demonstrated that LMP prevented cell death induced by $\mathrm{H}_{2} \mathrm{O}_{2}$. The number of coherent cells after LMP loading for $3 \mathrm{~h}$ was significantly higher than

$$
\text { LIU, J. et al. }
$$

that after $3 \mathrm{~h}$ loading of $\mathrm{H}_{2} \mathrm{O}_{2}$. Statistical analysis demonstrated that the decrease in the adherent cell number induced by $\mathrm{H}_{2} \mathrm{O}_{2}$ loading were significant (Figure 3B). To determine whether the cell death of INS-1 cells was because of oxidative stress, the DCFH-DA assay was applied to evaluate intracellular ROS, as shown in Figure 4A. The intracellular ROS decreased significantly after LMP loading in INS-1 cells in the presence of $\mathrm{H}_{2} \mathrm{O}_{2}$ for 3h. Dichlorofluorescein fluorescence was assayed using confocal microscopy. The ROS content of $\mathrm{H}_{2} \mathrm{O}_{2}$-treated INS-1 cells was more than nine fold compared with the control cells (Figure 4B). The loading of LMP significantly decreased the level of ROS.

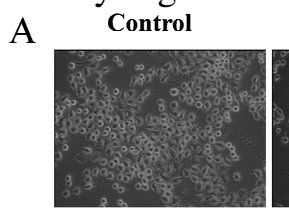

$\mathrm{H}_{2} \mathrm{O}_{2}$
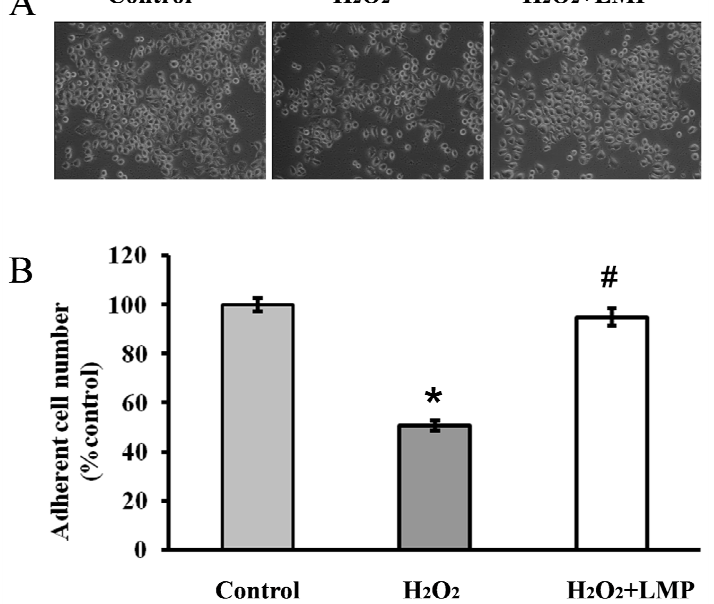

Figure 3. LMP protected cell viability after $\mathrm{H}_{2} \mathrm{O}_{2}$ exposure. (A) The cell images were obtained with a phasecontrast microscope at $3 \mathrm{~h}$ after treated with $\mathrm{H}_{2} \mathrm{O}_{2}$ in the absence or presence of $2.0 \mathrm{mg} \mathrm{mL}^{-1} \mathrm{LMP}$. (B) The numbers of adherent cells were expressed as percentage of the number of control cells, Data were mean $\pm \mathrm{SD}$ of three parallel measurements. ${ }^{*} p<0.05$ vs. the levels of control. $\# p<0.05$ vs. the levels of cells untreated with $\mathrm{H}_{2} \mathrm{O}_{2}$
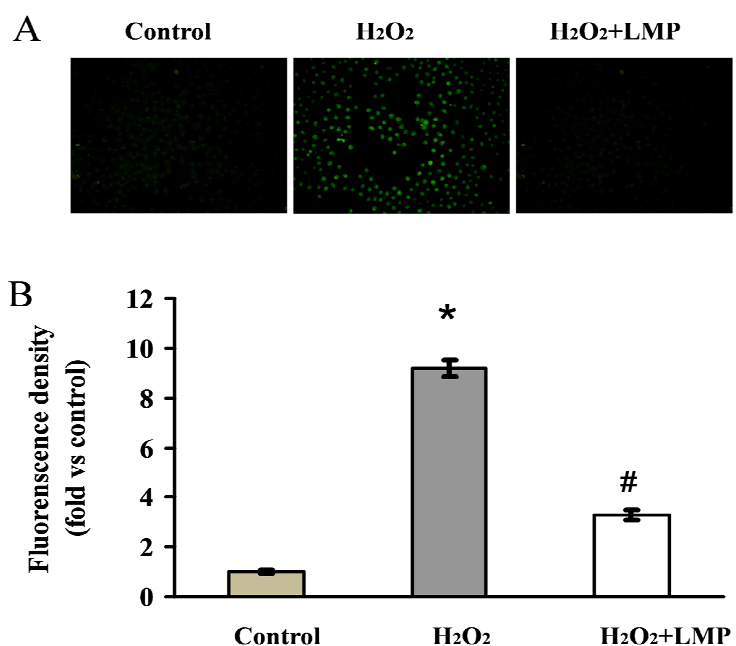

Figure 4. Effect of LMP on intracellular ROS.(A) The cell images were obtained with fluorescence microscope at $3 \mathrm{~h}$ after treated with $\mathrm{H}_{2} \mathrm{O}_{2}$ in the absence or presence of $2.0 \mathrm{mg} \mathrm{mL}^{-1} \mathrm{LMP}$. (B) Fluorescent intensities of DCFH-DA are expressed as fold increases of the of control level, Data were mean \pm SD of three parallel measurements $* p<0.05$ vs. the levels of control. $\# p<0.05$ vs. the levels of cells untreated with LMP. 


\section{LMP inhibit cell apoptosis induced by $\mathrm{H}_{2} \mathrm{O}_{2}$}

Many studies have shown that reduced $\beta$ cell mass is one of important determining risk factor for diabetes. (XU et al., 2009) Pancreatic $\beta$ cells are sensitive to ROS damage which can induce cell apoptosis in many kinds of cell lines. It has been proposed that treatment using antioxidants can prevent pancreatic $\beta$ cells apoptosis. Our results indicated that $0.25 \mathrm{mM} \mathrm{H}_{2} \mathrm{O}_{2}$ can induce the
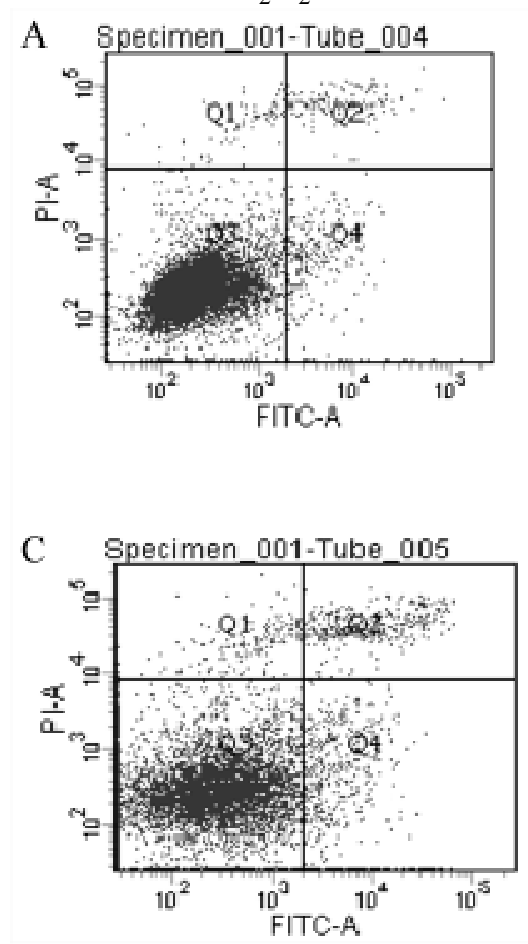

Figure 5. LMP inhibited INS-1 cell apoptosis induced by $\mathrm{H}_{2} \mathrm{O}_{2}$. (A) Control group. (B) Measurement of INS-1 cell apoptosis with $\mathrm{H}_{2} \mathrm{O}_{2}$ treatment. (C) Measurement of INS-1 cell apoptosis induced by $\mathrm{H}_{2} \mathrm{O}_{2}$ in the presence of $2.0 \mathrm{mg} \mathrm{mL}^{-1} \mathrm{LMP}$. (D) Statistical analysis of apoptosis rate. Data were mean $\pm \mathrm{SD}$ of three parallel measurements $* p<0.05$ vs. the levels of control. $\# p<0.05$ vs. the levels of cells untreated with LMP.

\section{CONCLUSIONS}

LMP exhibited significantly strong radical scavenging activity.

The radical scavenging rate of the DPPH radical, hydroxyl radical and superoxide anion radical were $80.32 \pm 2.58 \%, 92.56 \pm 3.11 \%$ and $93.73 \pm 2.82 \%$, respectively. The reducing power and inhibition of lipid peroxidation activity were as strong as the positive control.

LMP reduced the level of intracellular reactive oxygen species and inhibited cell apoptosis significantly, which appeared to be because of its antioxidant characteristics. The results open perspectives for studies of LMP in the treatment of diabetes

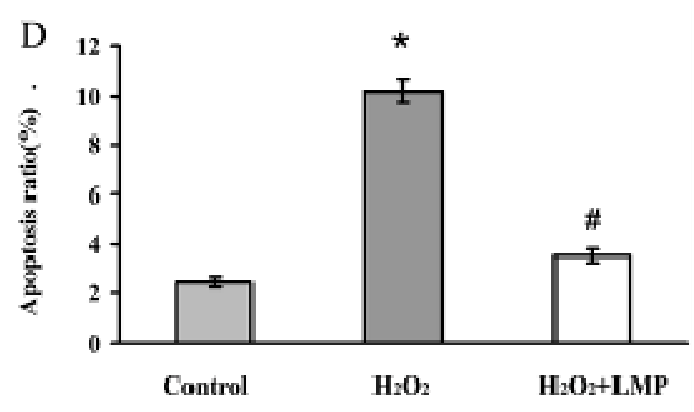

apoptosis of pancreatic $\beta$ cell with a $10.23 \pm 0.87 \%$ apoptosis rate, whereas LMP can reduce the pancreatic $\beta$ cell apoptosis to a $3.26 \pm 0.28 \%$ apoptosis rate (Figure 5). The results indicated that LMP can inhibit pancreatic $\beta$ cell apoptosis by reducing oxidative stress, which suggests that LMP has the potential to be used as an antioxidant for diabetes prevention.

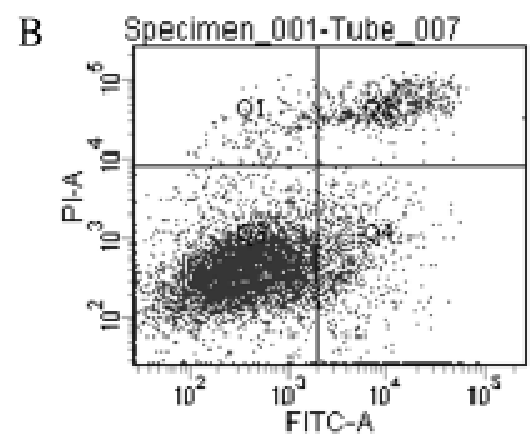

\section{ACKNOWLEDGEMENTS}

This study was supported by the National Natural Science Foundation of China (No. 31240005), Program for Liaoning Excellent Talents in University (No. LJQ2013002), Cultivation Plan for Youth Agricultural Science and Technology Innovative Talents of Liaoning Province (No. 2015013), Project Supported by Scientific Research Fund of Liaoning Provincial Education Department (No. L2014007), the Agriculture research Program of Science and Technology Department of Liaoning Province, China (No.2011211001), Startup Foundation for Doctors of Liaoning University, Innovation Team Project from the Education Department of Liaoning Province (No.LT2015011). 
RESUMO: O estresse oxidativo tem uma função biológica importante em muitos organismos. A ruptura do equilíbrio delicado entre a geração de espécies reativas de oxigênio (ROS) e sistemas de eliminação de antioxidantes pode levar a muitos problemas de saúde. Polissacarídeos extraídos do corpo fungos frutas e micélio têm vários benefícios potenciais para a saúde. Neste estudo, foram investigados os efeitos celulares e capacidade de proteção antioxidante de um polissacarídeo isolado a partir de Lentinus edodes micélios (LMP). As propriedades antioxidantes da LMP foram rastreadas utilizando eliminação de radicais (1, 1-difenil-2-picrilhidrazil (DPPH), hidroxilo e anião superóxido), e a redução da potência de inibição de ensaios de peroxidação lipídica. Espécies reativas de oxigénio intracelulares (ROS), em resposta ao $\mathrm{H}_{2} \mathrm{O}_{2}$, foi determinada pelo ensaio de diacetato de dicloro-di-hidro-f luoresceina (DCFH-DA). INS-1 células a apoptose foi detectada utilizando análise de citometria de fluxo. Os resultados mostraram que LMP exibiu significativamente forte atividade de eliminação de radicais. $\mathrm{Na}$ concentração de $2 \mathrm{mg} \mathrm{mL} \mathrm{mL}^{-1} \mathrm{DPPH}$ radical, radical hidroxilo e anião superóxido velocidades de eliminação de radicais livres são 80,32 $\pm 2,58 \%, 92,56 \pm 3,11 \% 93,73 \pm$ $2,82 \%$, respectivamente. O poder redutor e inibição da peroxidação lipídica de LMP foram tão forte quanto o controlo positivo. LMP aliviou a nível de espécies reativas de oxigênio intracelular e apoptose de células da ilhota inibiu significativamente. Sugere-se que LMP pode ser utilizado como um reagente complementar para a diabetes a prevenção e terapia.

PALAVRAS-CHAVE: Lentinus edodes mycelia. Polissacarideo. Antioxidante. Estresse oxidativo.

\section{REFERENCES}

CAO, X.; LIU, R.; LIU, J.; HUO, Y.; YANG, W.; ZENG, M.; YANG, C. A Novel Polysaccharide from Lentinus edodes Mycelia Exhibits Potential Antitumor Activity on Laryngeal Squamous Cancer Cell Line Hep2. Appl Biochem Biotechnol, Shenyang, v. 171, n. 6, p. 1444-1453, Nov. 2013. http://dx.doi.org/10.1007/s12010-013-0441-6.

CHEN, H.; JU, Y.; LI, J.; YU, M. Antioxidant activities of polysaccharides from Lentinus edodes and their significance for disease prevention. Int J Biol Macromol, Xi'an, v. 50, n. 1, p. 214-218, Jan. 2012. http://dx.doi.org/10.1016/j.ijbiomac.2011.10.027.

CHEN, J.; ZHANG, T.; JIANG, B.; MU, W.; MIAO, M. Characterization and antioxidant activity of Ginkgo biloba exocarp polysaccharides. Carbohydr Polym, Wuxi, v. 87, n. 1, p. 40-45, Jan. 2012. http://dx.doi.org/10.1016/j.carbpol.2011.06.083.

CHEN, R.; LIU, Z.; ZHAO, J.; CHEN, R.; MENG, F.; ZHANG, M.; GE, W. Antioxidant and immunobiological activity of water-soluble polysaccharide fractions purified from Acanthopanax senticosu. Food Chem, Changchun, v. 127, n. 2, p. 434-440, Jul. 2011. http://dx.doi.org/10.1016/j.foodchem.2010.12.143.

CHEN, X.; ZHONG, H. Y.; ZENG, J. H.; GE, J. The pharmacological effect of polysaccharides from Lentinus edodes on the oxidative status and expression of VCAM-1mRNA of thoracic aorta endothelial cell in high-fatdiet rats. Carbohydr Polym, Changsha, v. 74, n. 3, p. 445-450, Nov. 2008.

http://dx.doi.org/10.1016/j.carbpol.2008.03.018.

DURACKOVÁ, Z. Some Current Insights into Oxidative Stress. Physiol Res, Bratislava, v. 59, n. 4, p. 459469, Nov. 2010.

FUJIMOTO, S.; MUKAI, E.; INAGAKI, N. Role of endogenous ROS production in impaired metabolismsecretion coupling of diabetic pancreatic $\beta$ cells. Prog Biophys Mol Biol, Sakyo-ku, v. 107, n. 2, p. 304-310, Nov. 2011. http://dx.doi.org/10.1016/j.pbiomolbio.2011.07.013.

HE, N. W.; YANG, X. B.; JIAO, Y. D.; TIAN, L. M.; ZHAO, Y. Characterisation of antioxidant and antiproliferative acidic polysaccharides from Chinese wolfberry fruits. Food Chem, Xi'an, v. 133, n. 3, p. 978989, Aug. 2012. http://dx.doi.org/10.1016/j.foodchem.2012.02.018. 
LEE, E.; RYU, G. R.; KO, S. H.; AHN, Y. B.; YOON, K. H.; HA, H.; SONG, K. H. Antioxidant treatment may protect pancreatic beta cells through the attenuation of islet fibrosis in an animal model of type 2 diabetes.

Biochem Biophys Res Commun, Seoul, v. 414, n. 2, p. 397-402, Oct. 2011.

http://dx.doi.org/10.1016/j.bbrc.2011.09.087.

LEE, S. H.; KANG, S. M.; KO, S. C.; KANG, M. C.; JEON, Y. J. Octaphlorethol A, a novel phenolic compound isolated from Ishige foliacea, protects against streptozotocin-induced pancreatic $\beta$ cell damage by reducing oxidative stress and apoptosis. Food Chem Toxicol, Chungju, v. 59, p. 643-649, Sep. 2013. http://dx.doi.org/10.1016/j.fct.2013.07.011.

LI, J. W.; LIU, Y. F.; FAN, L. P.; AI, L. Z.; SHAN, L. A. Antioxidant activities of polysaccharides from the fruiting bodies of Zizyphus Jujuba cv. Jinsixiaozao. Carbohydr Polym, Wuxi, v. 84, n.1, p. 390-394, Feb. 2011. http://dx.doi.org/10.1016/j.carbpol.2010.11.051.

LIN, N.; ZHANG, H.; SU, Q. Advanced glycation end-products induce injury to pancreatic beta cells through oxidative stress. Diabetes Metab, Shanghai, v. 38, n. 3, p. 250-257, Jun. 2012.

http://dx.doi.org/10.1016/j.diabet.2012.01.003.

LIU, C.; CHANG, J.; ZHANG, L.; ZHANG, J.; LI, S. Purification and antioxidant activity of a polysaccharide from bulbs of Fritillaria ussuriensis Maxim. Int J Biol Macromol, Chungju, v. 50, n. 4, p. 1075-1080, May 2012. http://dx.doi.org/10.1016/j.ijbiomac.2012.03.006.

LIU, X.; SUN, Z.; ZHANG, M.; MENG, X.; XIA, X.; YUAN, W.; XUE, F.; LIU, C. Antioxidant and antihyperlipidemic activities of polysaccharides from sea cucumber. Apostichopus japonicus. Carbohydr Polym, Jinan, v. 90, n. 4, p. 1664-1670, Nov. 2012.

http://dx.doi.org/10.1016/j.carbpol.2012.07.047.

LU, X.; KAMBE, F.; CAO, X.; KOZAKI, Y.; KAJI, T.; ISHII, T.; SEO, H. DHCR24 is a hydrogen peroxide scavenger, protecting cells from oxidative-stress-induced apoptosis. Endocrinology, Furo-cho, v. 149, n. 7, p. 3267-3273, Mar. 2008. http://dx.doi.org/10.1210/en.2008-0024.

MA, L.; CHEN, H.; ZHANG, Y.; ZHANG, N.; FU, L. Chemical modification and antioxidant activities of polysaccharide from mushroom Inonotus obliquus. Carbohydr Polym, Tianjin, v. 89, n. 2, p. 371-378, Jun. 2012. http://dx.doi.org/10.1016/j.carbpol.2012.03.016.

MCCABE, C.; SAMALI, A.; O'BRIEN, T. $\beta$ cell cytoprotective strategies: Establishing the relative roles for iNOS and ROS. Biochem Biophys Res Commun, Galway, v. 342, n. 4, p. 1240-1248, Apr. 2006. http://dx.doi.org/10.1016/j.bbrc.2006.02.092.

MEHMETI, I.; GURGUL-CONVEY, E.; LENZEN, S.; LORTZ, S. Induction of the intrinsic apoptosis pathway in insulin-secreting cells is dependent on oxidative damage of mitochondria but independent of caspase-12 activation. BBA MOL CELL RES, Hannover, v. 1813, n. 10, p. 1827-1835, Oct. 2011. http://dx.doi.org/10.1016/j.bbamcr.2011.06.022.

Mirmiran, P.; Bahadoran, Z.; Azizi, F. Lipid Accumulation Product Is Associated with Insulin Resistance, Lipid Peroxidation, and Systemic Inflammation in Type 2 Diabetic Patients. Endocrinol Metab, Tehran, v. 24, n. 4, p. 443-449, Dec. 2014.

http://dx.doi.org/10.3803/EnM.2014.29.4.443.

RAINS, J. L.; JAIN, S. K. Oxidative stress, insulin signaling, and diabetes. Free Radicial Bio Med, Shreveport, v. 50, n. 5, p. 567-575, Mar. 2011.

http://dx.doi.org/10.1016/j.freeradbiomed.2010.12.006. 
SOARES, A. A.; DE SOUZA, C. G. M.; DANIEL, F. M.; FERRARI, G. P.; DA COSTA, S. M. G.; PERALTA, R. M. Antioxidant activity and total phenolic content of Agaricus brasiliensis (Agaricus blazei Murril) in two stages of maturity. Food Chem, Maringá, v. 112, n. 4, p. 775-781, Feb. 2009. http://dx.doi.org/10.1016/j.foodchem.2008.05.117.

SONG, H. F.; ZHANG, Q. B.; ZHANG, Z. S.; WANG, J. In vitro antioxidant activity of polysaccharides extracted from Bryopsis plumose. Carbohydr Polym, Beijing, v. 80, n. 4, p. 1057-1061, May 2010. http://dx.doi.org/10.1016/j.carbpol.2010.01.024.

TSRIMUANG, C.; KHAMMUANG, S.; CHIABLAEM, K.; SRISOMSAP, C.; SARNTHIM, R. Antioxidant properties and cytotoxicity of crude polysaccharides from Lentinus polychrous Lév. Food Chem, Maha Sarakham, v. 128, n. 3, p. 634-639, Oct. 2011. http://dx.doi.org/10.1016/j.foodchem.2011.03.077.

WANG, Y.; MAO, F.; WEI, X. Characterization and antioxidant activities of polysaccharides from leaves, flowers and seeds of green tea. Carbohydr Polym, Shanghai, v. 88, n. 1, p. 146-153. Mar. 2012. http://dx.doi.org/10.1016/j.carbpol.2011.11.083.

XIA, F. G.; FAN, J. H.; ZHU, M.; TONG, H. B. Antioxidant effects of a water-soluble proteoglycan isolated from the fruiting bodies of Pleurotus ostreatus. J Taiwan Inst Chem E, Jilin, v. 42, n. 3, p. 402-407, May 2011. http://dx.doi.org/10.1016/j.jtice.2010.08.012.

XU, J.; LONG, Y. S.; GOZAL, D.; EPSTEIN, P. N. $\beta$-cell death and proliferation after intermittent hypoxia: Role of oxidative stress. Free Radicial Bio Med, Louisvillev, v. 46, n. 6, p. 783-790, Mar. 2009. http://dx.doi.org/10.1016/j.freeradbiomed.2008.11.026.

ZHA, X. Q.; WANG, J. H.; YANG, X. F.; LIANG, H.; ZHAO, L. L.; BAO, S. H.; LUO J. P.; XU, Y. Y., \& ZHOU, B. B. Antioxidant properties of polysaccharide fractions with different molecular mass extracted with hot-water from rice bran. Carbohydr Polym, Hefei, v. 78, n. 3, p. 570-579, Oct. 2009.

http://dx.doi.org/10.1016/j.carbpol.2009.05.020.

ZHANG, M.; CUI, S. W.; CHEUNG P. C. K.; WANG, Q. Antitumor polysaccharides from mushrooms: a review on their isolation process, structural characteristics and antitumor activity. Trends Food Sci Tech, Guelph, v. 18, n. 1, p. 4-19, Jan. 2007. http://dx.doi.org/10.1016/j.tifs.2006.07.013. 